\title{
Addendum to the Remedial Investigation Report on Bear Creek Valley Operable Unit 2 \\ (Rust Spoil Area, Spoil Area 1, and SY-200 Yard) at the Oak Ridge Y-12 Plant, Oak Ridge, Tennessee
}

\section{Volume 1. Main Text}

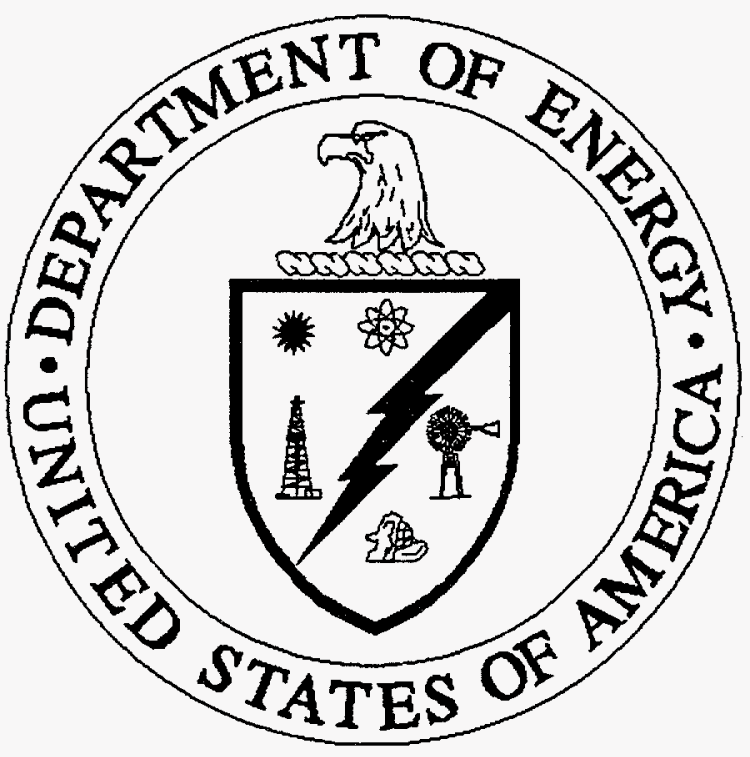

DEC 19295

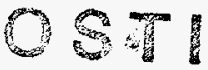

This addendum to the Remedial Investigation Report on Bear Creek Valiey Operable Unit 2 includes revisions to four chapters of information that were a part of the previously issued document entitled Remedial Investigation Report on Bear Creek Valley Operable Unit 2 (Rust Spoil Area, Spoil Area 1, and SY-200 Yard) at the Oak Ridge Y-12 Plant, Oak Ridge, Tennessee (DOE/OR/01-1273/N1\&D2). Specifically, Chaps. 2, 3, 4 , and 9 herein include minor changes made to the previously issued D2 version of the document; these changes are noted herein with a WordPerfect redline feature in the margin where the changes have occurred. Volume 1 of this document is not being reissued in its entirety as a D3 version because only the four chapters just mentioned have been affected by requested changes. Volume 2 of this document is not being reissued because there were no changes that needed to be incorporated in Volume 2. 


\section{Science Applications International Corporation}

contributed to the preparation of this document and should not be considered an eligible contractor for its review.

This report has been reproduced directly from the best available copy.

Available to DOE and DOE contractors from the Office of Scientific and Technical Information, P.O. Box 62, Oak Ridge, TN 37831; prices available from 615-576-8401 (fax 615-576-2865).

Available to the public from the National Technical Information Service, U.S. Department of Commerce, 5285 Port Royal Rd., Springfield, VA 22161. 


\section{DISCLAMIER}

Portions of this document may be illegible in electronic image products. Images are produced from the best available original document. 
Energy Systems Environmental Restoration Program Y-12 Environmental Restoration Program

\title{
Addendum to the Remedial Investigation Report on Bear Creek Valley Operable Unit 2 (Rust Spoil Area, Spoil Area 1, and SY-200 Yard) at the Oak Ridge Y-12 Plant Oak Ridge, Tennessee
}

Volume 1. Main Text

Date Issued-April 1995

\author{
Prepared by \\ Science Applications International Corporation \\ Oak Ridge, Tennessee \\ under subcontract 43B-99069C, Y-05 \\ Prepared for \\ U.S. Department of Energy \\ Office of Environmental Management \\ under budget and reporting code EW 20 \\ Environmental Restoration and Waste Management Programs \\ OAK RIDGE Y-12 PLANT \\ Oak Ridge, Tennessee 37831-8169 \\ managed by \\ MARTIN MARIETTA ENERGY SYSTEMS, INC. \\ for the \\ U.S. DEPARTMENT OF ENERGY \\ under contract DE-AC05-84OR21400
}





\section{PREFACE}

This addendum to the Remedial Investigation (RI) Report on Bear Creek Valley Operable Unit (OU) 2 at the Oak Ridge Y-12 Plant (DOE/OR/01-1273/V1\&D2/A1) was prepared in accordance with requirements under the Comprehensive Environmental Response, Compensation, and Liability Act (CERCLA) for reporting the results of a site characterization for public review. This work was performed under Work Breakdown Structure 1.4.12.1.1.02.42.10. This addendum is a supplement to a document that was previously issued in January 1995 and that provided the Environmental Restoration Program with information about the results of the 1993 investigation performed at OU 2. The January 1995 D2 version of the RI Report on Bear Creek Valley OU 2 included information on risk assessments that have evaluated impacts to human health and the environment. Information provided in the document formed the basis for the development of the Feasibility Study Report, DOE/OR/02-1279\&D1.

This addendum includes revisions to four chapters of information that were a part of the document issued in January 1995. Specifically, it includes revisions to Chaps. 2, 3, 4, and 9; these changes have been noted herein with the WordPerfect redline feature in the margin where changes have occurred. Volume 1 of this document is not being reissued in its entirety as a D3 version because only the four chapters just mentioned have been affected by requested changes. Note also that Volume 2 of this RI Report on Bear Creek Valley OU 2 is not being reissued in conjunction with Volume 1 of this document because there have been no changes requested or made to the previously issued version of Volume 2 of this document. 


\section{CONTENTS}

Table 2.9 Threatened and Endangered Plant and Animal Species Potentially Occurring on the Oak Ridge Reservation

Fig. 2.20 General Wildife Habitats on the ORR (Only the page number has changed)

Text from End of Sect. 2.7.2 (Terrestrial Fauna) $2-51$

Remainder of Chap. 2 after changes made to Sect. 2.7.2 $2-52$

Fig. 3.57 Ambient Air Monitoring Stations at the Y-12 Plant [Included here because text on the back of the figure (page 3-198) has changed] . . . . 3-197

Text from End of Sect. 3.2.7 (Air Data) . . . . . . . . . . . . . . 3-198

Text in Sect. 4.5 .4 (Rare, Threatened, or Endangered Species) . . . . . . . . 4-11

Chapter 9 (References) $\ldots \ldots \ldots \ldots \ldots \ldots \ldots \ldots \ldots \ldots \ldots \ldots \ldots . \ldots \ldots$ 
Table 29. Threatened and endangered plant and animal species potentially occurring on the Oak Ridge Reservation

\begin{tabular}{|c|c|c|c|}
\hline \multirow[b]{2}{*}{ Scientific name } & \multirow[b]{2}{*}{ Common name } & \multicolumn{2}{|c|}{ Status } \\
\hline & & Federal $^{a}$ & State $^{b}$ \\
\hline \multicolumn{4}{|c|}{ Flora } \\
\hline Aureolaria patula & Spreading false foxglove & $\mathrm{Cl}$ & $\mathrm{E}$ \\
\hline Carex gravida & Gravid sedge & & $\mathbf{S}$ \\
\hline Cimicifuge rubifolia & Appalachian bugbane & $\mathrm{C} 2$ & $\mathrm{~T}$ \\
\hline Cypripedium acuale & Pink lady's slipper & & $E^{*}$ \\
\hline Delphinum exaltatum & Tall larkspur & $\mathrm{C} 2$ & $\mathbf{E}$ \\
\hline Diervilla lonicera & Northern bush honeysuckle & & $\mathbf{T}$ \\
\hline Elodea nuttallii & Nuttall waterweed & & $\mathbf{S}$ \\
\hline Fothergilla major & Mountain witch alder & & $\mathrm{T}$ \\
\hline Hydrastis canadensis & Golden seal & & $\mathbf{T}$ \\
\hline Juglans cinerea & Butternut & $\mathrm{C} 2$ & $\mathbf{T}$ \\
\hline Lilium canadense & Canada lily & & $\mathbf{T}$ \\
\hline Lilium michiganense & Michigan lily & & $\mathbf{T}$ \\
\hline Liparis loeselii & Fen orchid & & $\mathrm{E}$ \\
\hline Panax quinqifolius & Ginseng & $3 C$ & $\mathbf{T}$ \\
\hline Platanthera flava v. herbiola & Tuberculed rein orchid & & $\mathbf{T}$ \\
\hline Platanthera peramoena & Purple fringeless orchid & $3 C$ & $\mathrm{~T}$ \\
\hline Saxifraga careyana & Carey saxifrage & C3 & $\mathbf{S}$ \\
\hline Spiranthes ovalis & Lesser ladies tresses & & $\mathbf{s}$ \\
\hline Spirata virginiana & Virginia spiraes & $\mathbf{T}$ & $\mathbf{E}$ \\
\hline \multicolumn{4}{|c|}{ Mammals } \\
\hline Lutra canadensis & River otter & & $\mathrm{T}$ \\
\hline Myotis grisescens & Gray bat & $\mathrm{E}$ & $\mathbf{E}$ \\
\hline Myotis sodalis & Indiana bat & $\mathrm{E}$ & $\mathrm{E}$ \\
\hline \multicolumn{4}{|c|}{ Birds } \\
\hline Circus cyaneus & Northern harrier & & D \\
\hline Falco peregrinus & Peregrine falcon & $\mathbf{E}$ & $\mathrm{E}$ \\
\hline Haliaeetus leucocephalus & Bald eagle & E & $\mathrm{E}$ \\
\hline Pandion haliaetus & Osprey & & \\
\hline Accipiter striatus & Sharp-shinned hawk & & $\mathrm{E}$ \\
\hline
\end{tabular}


Table 2.9 (continued)

\begin{tabular}{|c|c|c|c|}
\hline \multirow[b]{2}{*}{ Scientific name } & \multirow[b]{2}{*}{ Common name } & \multicolumn{2}{|c|}{ Status } \\
\hline & & Federal $^{a}$ & State $^{b}$ \\
\hline Accipiter cooperii & Cooper's hawk & & $\mathbf{T}$ \\
\hline Aimophila aestivalis & Bachman's sparrow & & $\mathrm{E}$ \\
\hline Ammodramus savannarum & Grasshopper sparrow & & $\mathbf{T}$ \\
\hline Nycticorax nycticorax & Black-crowned night heron & & D \\
\hline Coragyps atratus & Black vulture & & D \\
\hline Buteo lineatus & Red-shouldered hawk & & D \\
\hline Tyto alba & Barn owl & & D \\
\hline Picoides borealis & Red-cockaded woodpecker & $\mathrm{E}$ & $\mathrm{E}$ \\
\hline Thryomanes bewickii & Bewick's wren & & $\mathrm{T}$ \\
\hline \multicolumn{4}{|c|}{ Fish } \\
\hline Hemitremia flammea & Flame chub & & D \\
\hline Phoxinus tennesseensis & Tennessee dace & & $\mathrm{D}$ \\
\hline \multicolumn{4}{|c|}{ Amphibians } \\
\hline Aneides aeneus & Green salamander & & $\mathrm{D}$ \\
\hline Cyptobranthus alleganiensis & Hellbender & $\mathrm{C} 2$ & D \\
\hline Gryrinophilus palleucus & Tennessee cave salamander & $\mathrm{C} 2$ & $\mathbf{T}$ \\
\hline \multicolumn{4}{|c|}{ Reptiles } \\
\hline Chrysemys scripta troosti & Cumberland turtle & & $\mathrm{D}$ \\
\hline Attenuatus longicaudus & Eastern slender glass lizard & & $\mathrm{D}$ \\
\hline Pituophis melanoleucus & Northern pine snake & $\mathrm{C} 2$ & $\mathbf{T}$ \\
\hline Cnemiduphurus sexlineatus & Six-lined racerunner & & $\mathbf{D}$ \\
\hline \multicolumn{4}{|c|}{ Birds } \\
\hline Melanerpes erythrocephalus & Red-headed woodpecker & & $\mathbf{D}$ \\
\hline Buteo lineatus & Red-shouldered hawk & & D \\
\hline Passerherbulus henslowii & Henslow's sparrow & C & \\
\hline Chundestes grammacus & Lark sparrow & & D \\
\hline Pgoectes gramineus & Vesper sparrow & & D \\
\hline \multicolumn{4}{|c|}{ Mammals } \\
\hline Plecutus rafinesquii & Rafinesque's big-earred bat & C & $\mathrm{D}$ \\
\hline Sorex dispar & Long-tailed shrew & C & D \\
\hline Sorex cinereus & Masked shrew & & $\mathrm{D}$ \\
\hline
\end{tabular}


April 17, 1995

Ms. Sherry L. Lankford

Department of Energy, Oak Ridge Operations

Post Office Box 2001

Oak Ridge, Tennessee 37830-8501

Dear Ms. Lankford:

Transmittal of Addendum to Remedial Investigation Report on Bear Creek Valley Operable Unit 2 (Rust Spoil Area, Spoil Area 1 and SY-200 Yard) at the Oak Ridge Y-12 Plant, Oak Ridge, Tennessee (DOE/OR/01-1273/V1\&D2/A1)

Enclosed are ten copies of the Addendum to Remedial Investigation Report on Bear Creek Valley Operable Unit 2 (Rust Spoil Area, Spoil Area 1 and SY-200 Yard) at the Oak Ridge Y-12 Plant, Oak Ridge, Tennessee (DOE/OR/01-1273/V1\&D2/A1). This document is issued in response to comments by the Tennessee Department of Environment and Conservation (TDEC) in a letter dated February 15, 1995, from R. Doug McCoy to Nelson Lingle. Also enclosed is a Comment Response Summary Table addressing these comments. Please submit the appropriate number of copies of both the Addendum and the Comment Response Summary Table to the Environmental Protection Agency (EPA) and TDEC for their records.

The EPA approved the D2 version of this document in a March 2, 1995, letter from Fernando Rivera to Nelson Lingle. Issuance of this Addendum finalizes the approval process for this document.

Please sign and return the attached acknowledgment form as documentation of your receipt of this document. You may contact Judy Hodgins at 576-2368 with any questions that you have.

Sincerely,

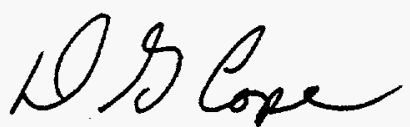

Dennis G. Cope, Program Manager

Y-12 Environmental Restoration

DGC:JAHodgins:tkb

cc: S. W. Wiley, TOA

cc/enc: File-ER Document Management Center-RC 
Page 2

April 17, 1995

I acknowledge receipt of ten copies of the document listed below and will transmit the required number of copies of this document to the Environmental Protection Agency and the Tennessee Department of Environment and Conservation.

Signed: Date of Signature:

Sherry L. Lankford

Document: $\quad$ Addendum to the Remedial Investigation Report on Bear Creek Valley Operable Unit 2 (Rust Spoil Area, Spoil Area 1 and SY-200 Yard) at the Oak Ridge Y-12 Plant, Oak Ridge, Tennessee (DOE/OR/01-1273/V1\&D2/A1) 


\begin{tabular}{|c|c|c|c|c|c|}
\hline \multicolumn{6}{|c|}{$\begin{array}{l}\text { RESPONSE TO COMMENTS } \\
\text { Bear Creek OU2 Remedial Investigation Plan }\end{array}$} \\
\hline No. & Page/Section/ & Comment & $\begin{array}{l}\text { Accept/ } \\
\text { Reject }\end{array}$ & Response & $\begin{array}{l}\text { Revision } \\
\text { Location }\end{array}$ \\
\hline \multicolumn{6}{|c|}{ R. Doug McCoy } \\
\hline 1. & $\begin{array}{l}\text { Page 2-47, } \\
\text { Table 2.9 }\end{array}$ & $\begin{array}{l}\text { Animals and plants in this table in the D1 } \\
\text { document are omitted in the D2 (e.g. } \\
\text { mammals). Please update this table with the } \\
\text { attached endangered species list (from An } \\
\text { Approach and Strategy for Performing } \\
\text { Ecological Risk Assessments for the US } \\
\text { Department of Energy's Oak Ridge } \\
\text { Reservation: 1994 Edition, ES/ERTM-33/RI. }\end{array}$ & & $\begin{array}{l}\text { Animals and plants omitted from the } \\
\text { D2 version of Table } 2.9 \text { were added } \\
\text { back into the table. The table was } \\
\text { updated using the attached endangered } \\
\text { species list that was provided. }\end{array}$ & Table 2.9 \\
\hline 2. & $\begin{array}{l}\text { Page 2-50, } \\
\text { Paragraph 4, } \\
\text { Threatened and } \\
\text { Endangered } \\
\text { Species }\end{array}$ & $\begin{array}{l}\text { Please edit this paragraph to reflect the species } \\
\text { listed on Table } 2.9 \text {, as was requested in } \\
\text { comment } 6-A \text { in the State's original comment } \\
\text { letter on this document. }\end{array}$ & & $\begin{array}{l}\text { Agree. Change made to paragraph as } \\
\text { requested. }\end{array}$ & $\begin{array}{l}\text { Sect } 2.7 .2 \\
\text { p. } 2-5 i\end{array}$ \\
\hline
\end{tabular}




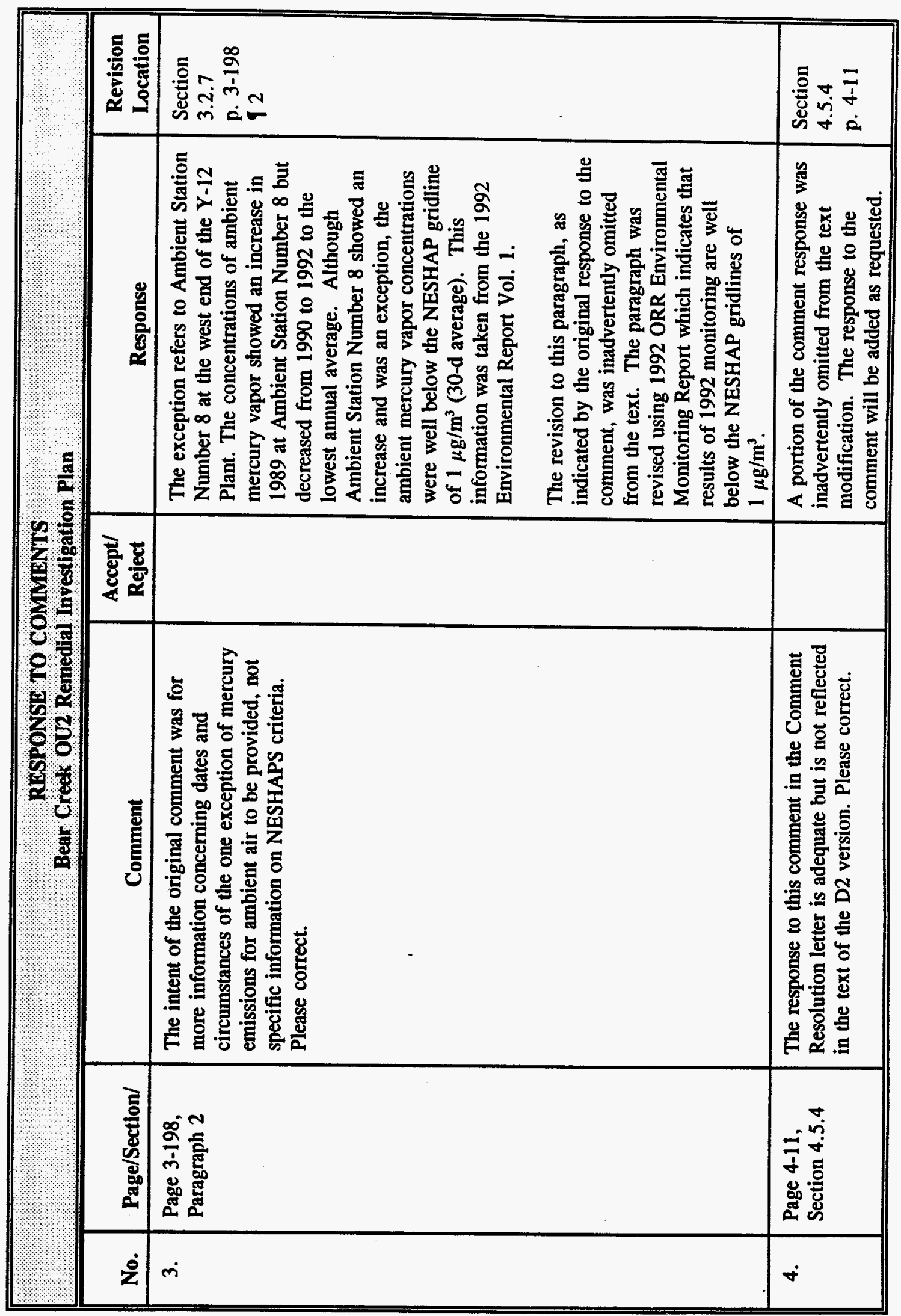

95-036P/032095 
Table 29 (continued)

\begin{tabular}{llcc}
\hline & & \multicolumn{2}{c}{ Status } \\
\cline { 3 - 3 } \multicolumn{1}{c}{ Scientific name } & \multicolumn{1}{c}{ Common name } & Federal $^{a}$ & State $^{b}$ \\
\hline Sorex fumeus & Smokey shrew & D \\
Sorex longirostris & Southeastern shrew & D \\
Felis cancolor & Cougar & E & \\
\hline
\end{tabular}

${ }^{a}$ Federal status codes:

$\mathbf{E}=$ Endangered.

$\mathrm{T}=$ Threatened.

C1 = Taxa for which the USFWS has on file substantial information on biological vulnerability and threats to support the appropriateness to list them as endangered or threatened species. Included are those taxa whose status in recent past is known, but may have already become extinct.

C2 = Taxa for which information now in possession of the service indicated that proposing to list them as endangered or threatened is appropriate, but for which substantial data on biological vuinerability and threat(s) are not currently known or on file to support a proposed rule.

C3 = Taxa that are no longer being considered for listing as threatened or endangered species.

$3 C=$ Taxa that have proven to be more abundant or widespread than was previously believed and/or those that are not subject to any identifiable threat.

${ }^{b}$ State status codes:

$\mathrm{E}=$ Endangered.

$\mathbf{E}^{*}=$ Endangered due to commercial exploitation.

$T=$ Threatened.

$S=$ Special concern.

$\mathrm{D}=$ Deemed in need of management.

Sources:

Cunningham et al. 1993. Resource Management Plan for the Oak Ridge Reservation, Vol. 29: Rare Plants on the Oak Ridge Reservation, ORNL/NERP-7. Oak Ridge, Tenn., August.

Memorandum from R. Kroodsma, Energy Systems, to R. E. Ambrose, SAIC, July 28, 1994.

Suter et al. 1994. An Approach and Strategy for Performing Ecological Risk Assessments for the U.S. DOE Oak Ridge Reservation, ES/ER/TM-33/R1. 


\section{General Wildlife Habitats}

\section{LECEND}

HARDWOODMIXED HARDWOCD HABITAT

-1. PINE PLANTATION HABTTAT

$\square$ AOUATK HABTAT

OLD FIELD AND GRASSLAND HABTAT

3. CAVE HABTTAT

BUILDING HABTTAT

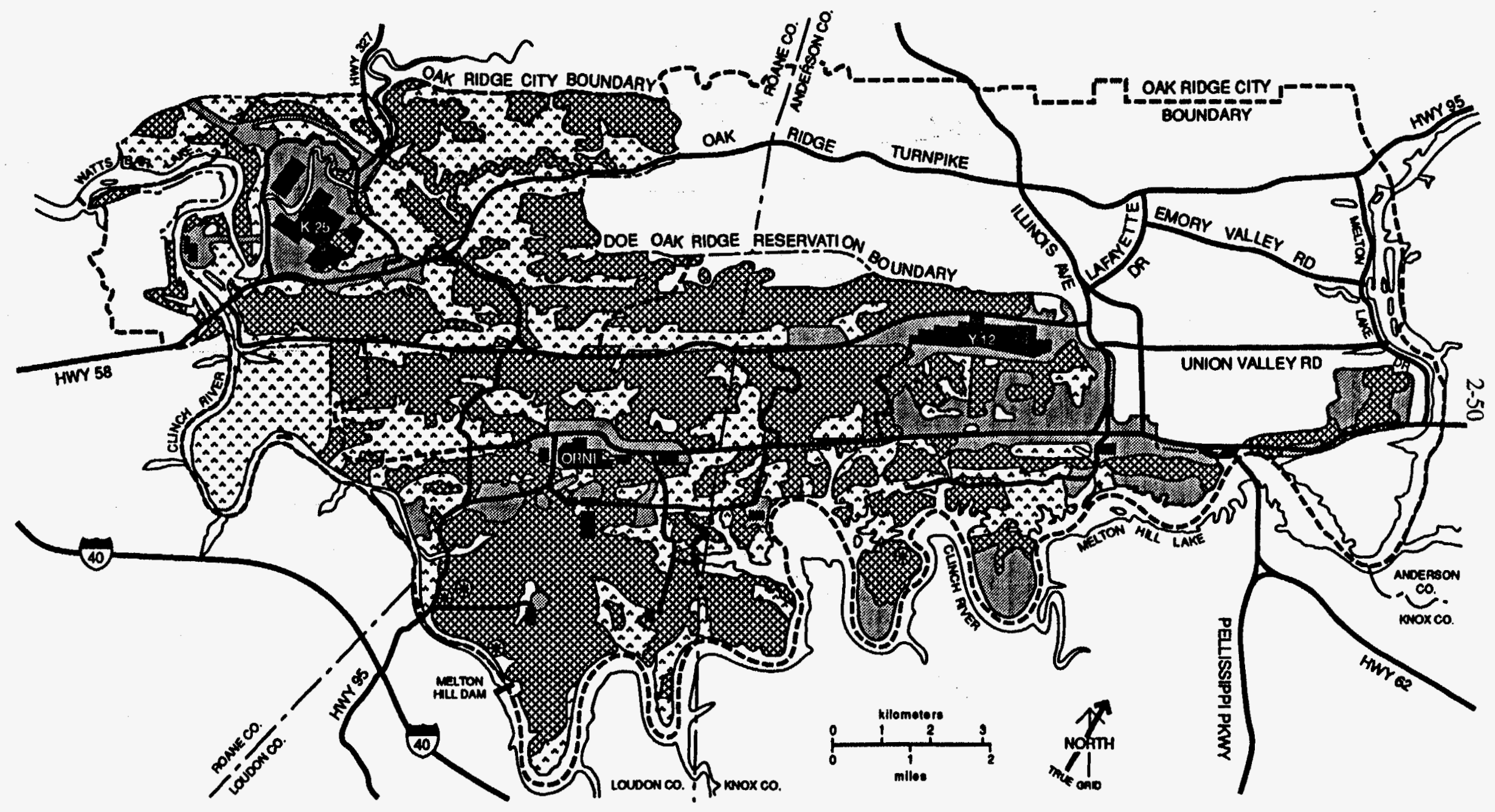

Fig. 2.20. General wildife habitats on the ORR (Source: DOE 1980). 
undergrowth develops and provides habitat for species similar to those found in early-to midstage hardwood-mixed and hardwood/conifer forests. Avian species have a low preference for the pure pine areas bordering the transmission line corridors. Pine warblers and whitethroated sparrows are common, but few other species are evident. These habitats are little used by reptiles or amphibians (Johnson 1964).

Old-field and grassland habitat. In the grassland/forb stage of vegetation, the principal species of small mammals are the southeastern shrew, least shrew, short-tailed shrew, eastern harvest mouse, hispid cotton rat, pine mouse, and the eastern cottontail rabbit. The eastern mole occurs in areas of loose soil. Closely mowed or grazed areas and dense kudzu growth is good habitat for the groundhog. Also found there are the striped skunk, coyote, red fox, and white-tailed deer. In more brushy vegetation, the white-footed mouse, golden mouse, and opossum may be found. Bird species found in this habitat include bobwhite, red-tailed hawk, field sparrow, towhee, blue grosbeak, meadowlark, and red-winged blackbird. The eastern bluebird population has increased with the establishment of bluebird nesting boxes. The yellow-breasted chat is found in old fields. Numerous frog, toad, lizard, and snake species are found in the old field areas.

Aquatic and riparian habitats. Many reptiles and amphibians occur in the various aquatic and wetland areas, including turtles, queen snakes, water snakes, salamanders, and frogs. The muskrat and beaver are bound closely to aquatic habitats. Rice rats, mink, and raccoons are also found in these areas. Many large mammals come frequently to this habitat to drink, and various small species are present at the water's edge. The American bald eagle occurs occasionally as a transient. Canada geese, great blue herons, and green-backed herons nest on the ORR.

Threatened and endangered species. Several mammal species on the federal and state list as threatened and/or endangered may occur on the ORR but have not been verified. These are listed in Table 2.9. There have been reported sightings of cougar on or in the area of the ORR, but this species probably does not occur on a regular basis. Also, the river otter has not yet been sighted on the ORR but was introduced to area streams and suitable habitats that exist on the ORR. Only two of the mammal species listed in Table 2.9 have been documented on the ORR: the Southeastern shrew and Indiana bat (Kroodsma 1987 and 1994). The pine snake is listed as threatened by the TWRA, and its presence in the Bear Creek watershed has been verified. The Cooper's hawk occurs in forests throughout the ORR as does the bald eagle. The Cooper's hawk is listed by the state as threatened while the bald eagle is listed as both a state and federal threatened species (Kroodsma 1994). Other birds recently documented on the ORR and listed by the state as endangered or in need of management include the grasshopper sparrow, black-crowned night heron, black vulture, redshouldered hawk, and barn owl. The Tennessee dace, a major constituent of the fish population above the weir at BCK 4.55 , is listed as a species in need of management. Its habitat is protected by the state of Tennessee (Starnes and Etnier 1980). Rare plants occurring on the Y-12 Plant site have been characterized by Hardy, Pounds, and Cook (1992). Table 2.9 lists all threatened and endangered plants and animal species potentially occurring on the ORR and the federal and/or state status of each.

\subsubsection{Aquatic Fauna}

There have been 19 species of fish found in Bear Creek in recent quantitative monitoring efforts conducted at 7 sites along virtually the entire length of the creek (Southworth et al. 
1992). Minnows [blacknose dace (Rhinichthys atratulus) and Tennessee dace (Phoxinos tennesseensis)], stoneroller (Campostoma anomalum), and creek chub (Semotilus atromaculatus) were the predominant fish species found upstream from the weir at BCK 4.55. Below the weir, larger species (northern hogsucker (Hypentelium nigricans), white sucker (Catastomus commersoni), and rockbass (Ambloplites rupestris) were more common; the diversity of minnow species increased; and darters were found. Conclusions of the recent fishmonitoring studies were that much of Bear Creek had limited fish fauna (low species richness) characterized by robust population parameters (high densities and biomass). The uppermost site (BCK 12.36) had no stable, resident fish population. Water from this site was commonly toxic to fathead minnow larvae in toxicity testing and contained high levels of dissolved salts as a result of input of contaminated groundwater from the S-3 Site. The next two monitoring sites downstream, BCK 11.83 and BCK 11.09, had low fish density and biomass in 1984 and 1985 but showed recovery in later sampling. No impacts on the fish of Bear Creek were evident in the vicinity of inputs from the Burial Grounds (BCK 9.91 and BCK 9.40) despite the fact that qualitative surveys found no fish in the tributaries (NT-6-8) draining that site.

The yellowfin madtom (Noturus flavipinnis), listed by the state as endangered, has been found in Bear Creek. The Tennessee dace, a major constituent of the fish population above the weir at BCK 4.55, is listed as a species in need of management. Its habitat is protected by the state of Tennessee (Starnes and Etnier 1980). In Bear Creek, it occurs at every site above the weir and in at least four tributaries (NT-13, NT-14, NT-18, and ST-7).

Quantitative sampling of benthic invertebrates was conducted monthly at nine sites from BCK 12.36 to BCK 3.25 during June 1984-May 1985 as part of Phase 1 of the ecological monitoring program for Bear Creek and at quarterly intervals thereafter (Southworth et al. 1992). A total of 126 distinguishable taxa were collected in Bear Creek, including crustaceans (Isopoda, Amphipoda, and Decapoda); aquatic worms (Oligochaeta); snails (Gastropoda); mussels (Pelecypoda); and insects (Insecta). There were 11 orders of insects collected in Bear Creek, including springtails (Collembola), mayflies (Ephemeroptera), dragonflies and damselflies (Odonata), crickets and grasshoppers (Orthoptera), stoneflies (Plecoptera), true bugs (Hemiptera), alderflies and fishflies (Megaloptera), caddisflies (Tricoptera), butterflies and moths (Lepidoptera), beetles (Coleoptera), and true flies (Diptera).

The invertebrate fauna of Bear Creek showed a pattern of increasing density, biomass, and taxonomic diversity and richness with increasing distance downstream from the uppermost sampling site (BCK 12.36) (Southworth et al. 1992). The paucity of benthic invertebrates in the upper reaches of Bear Creek contrasted sharply with reference sites (unimpacted streams of similar size), which had relatively diverse and abundant assemblages of macroinvertebrates.

In toxicity tests run in March 1988, water from BCK 12.36 and BCK 11.83 was toxic to Ceriodaphnia, an invertebrate test species, but not to fathead minnow larvae. At the time of these tests, stream flow in Bear Creek was higher than normal, and contaminants from the S-3 Ponds groundwater plume were diluted more than would be the case under baseflow conditions. Under low-flow conditions, it is likely that Bear Creek water would be toxic to Ceriodaphnia as far downstream as BCK 9.4. While evidence of adverse effects on the fish communities of Bear Creek was not noted at sites downstream from BCK 11.83, the benthic fauna appeared to be more sensitive, with clear differences in faunal composition from unimpacted reference sites at all sites except BCK 3.25 , where complete recovery appears to have occurred. 
Species intolerant of pollution (mayflies, stoneflies, and caddisflies) were absent in the upper reaches and became more common downstream. Mayflies, which are particularly sensitive to toxic metals, were virtually absent at all sites except BCK 3.25. Unlike the fish data, which provide evidence of ecological recovery in Bear Creek since 1984, the benthic macroinvertebrate fauna do not appear to have changed in a manner indicative of either improving or degrading water quality since 1984 (Southworth et al. 1992).

No threatened or endangered species of aquatic macroinvertebrates have been collected in Bear Creek.

A limited amount of data have been collected on the bioaccumulation of contaminants by aquatic biota in Bear Creek. Fish collected from lower Bear Creek contained elevated levels of mercury ( 0.2 to $0.5 \mu \mathrm{g} / \mathrm{g}$, wet weight) in 1982 (Van Winkle et al. 1984) and in 1984 (TVA 1986). While well below the U.S. Food and Drug Administration (FDA) action level, these data do indicate the presence of biologically available mercury in the Bear Creek system. Fish from lower Bear Creek were also analyzed for $\mathrm{Cd}, \mathrm{Cr}, \mathrm{Ag}, \mathrm{As}$, and $\mathrm{Ni}$ in 1984 (TVA 1986), and levels were found to be typical of fish from uncontaminated environments.

Polychlorinated biphenyl (PCB) contamination in fish from Bear Creek was evident in 1982, when rockbass collected from the lower reaches of the creek were found to contain $0.650 .29 \mathrm{ppm}$ (wet weight) PCBs (Turner et al. 1988). TVA analyzed fish from lower Bear Creek for organic priority pollutants, including PCBs in 1984; levels of all substances were below detection limits. Fish were collected from lower Bear Creek in 1987 as part of an effort to evaluate the importance (relative to other sources) of the upper EFPC discharge at New Hope Pond as a source of PCB contamination to lower Poplar Creek and the Clinch River. In this collection, PCBs in rockbass averaged $0.28 \pm 0.12 \mathrm{ppm}(\mathrm{n}=8)$, a value comparable to the level of contamination found in sunfish in the lower third of EFPC and well above the level typical of fish from uncontaminated sites $(0.02 \pm 0.01 \mathrm{ppm})$. Clams held in Bear Creek (BCK 4.55) for 1 month as part of the same study accumulated $1.01 \mathrm{ppm}$ PCBs (versus $0.05 \mathrm{ppm}$ in controls), indicating that Bear Creek now contains a source of biologically available PCBs.

PCB contamination has been observed in fish in EFPC, Poplar Creek, and the Clinch River/Watts Bar Reservoir downstream from Bear Creek (TVA 1986). It is unlikely that a substantial fraction of this contamination is attributable to Bear Creek because sources of PCBs and similar body burdens are found in EFPC far upstream from the mouth of Bear Creek (TVA 1986). A similar situation exists for mercury (TVA 1986). 


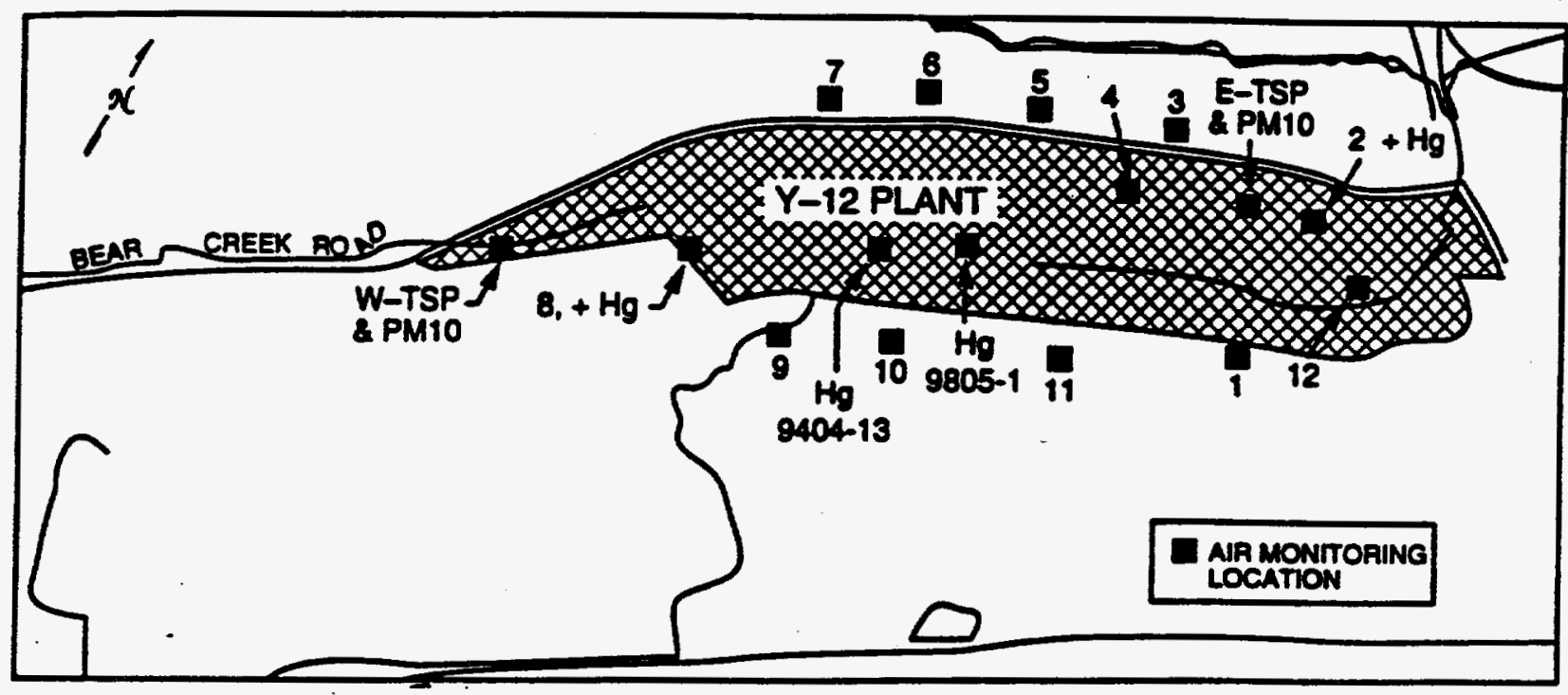

Fig. 3.57. Ambient air monitoring stations at the Y-12 Plant. 
Also monitored were ambient fluoride concentration, TSPs, and mercury concentrations. Ambient air concentrations of fluorides measured during 1992 at each of the Y-12 Plant perimeter air-monitoring fluoride stations were well below TDEC standards. TSP samples collected at the Y-12 Plant were not in excess of state primary or secondary standards in 1992 (Energy Systems 1993a).

Data for mercury in ambient air at five monitoring stations at the Y-12 Plant suggest that the environment and human health are not impacted by releases of mercury to the atmosphere. The results of 1992 monitoring indicate that on-site concentrations of mercury vapor are well below the National Emission Standards for Hazardous Air Pollutants (NESHAPs) guideline of $1 \mu \mathrm{g} / \mathrm{m}^{3}$ (a 30-d average) and the American Conference of Governmental Industrial Hygienist's threshold limit value of $50 \mu \mathrm{g} / \mathrm{m} 3$ (a time weighted average for an 8-h work day and 40-h work week). The data do show that ambient air mercury concentrations in the Y-12 Plant area are, in general, slightly elevated above natural background and may reach significantly elevated concentrations for short periods in localized areas. Disturbances, such as excavation of soil in contaminated areas, appear to elevate ambient air concentrations of mercury. Ambient air concentrations exhibited a seasonal pattern, with the highest values typically occurring in the warmer months.

\subsection{Radiation Survey Data}

The distribution of radiological contamination over the ORR and surrounding area has been assessed by airborne radiation surveys. These surveys have been flown since 1959, and a review of the aerial monitoring program is presented in Sect. 3.2.8.1.

\subsubsection{Historical data}

Historically, most of the radiation survey information on the ORR and surrounding area has been provided by the Aerial Measuring System (AMS), an aerial radiological surveillance capability maintained by DOE. The AMS is presently operated and maintained by EG\&G Energy Measurements, Inc. (EG\&G/EM) under contract to DOE.

The first aerial radiological survey of the ORR and surrounding area was conducted during the spring of 1959 by the USGS using a fixed-wing aircraft flying at a $152-\mathrm{m}(500-\mathrm{ft})$ altitude and 1.6-km (1-mile) line spacing. Its primary purpose was to characterize the radiogeology of the area. In 1973, EG\&G/EM conducted a survey using a fixed-wing aircraft flying at an altitude of $152 \mathrm{~m}(500 \mathrm{ft})$ and speed of 170 knots. Sites identified as having anomalous radiation levels were re-surveyed with a helicopter-mounted AMS flying at an altitude of $76 \mathrm{~m}(250 \mathrm{ft})$ and speed of 70 knots. The increased sensitivity provided detailed coverage of radiological activity at the anomalous radiation sites.

In 1980 , an aerial radiological survey of the entire ORR and nearby surrounding area, encompassing $440 \mathrm{~km}^{2}\left(170 \mathrm{~m}^{2}\right)$, was conducted. The survey consisted of parallel flight lines $152 \mathrm{~m}(500 \mathrm{ft})$ apart at an altitude of $91 \mathrm{~m}(300 \mathrm{ft})$. During September 12-29, 1989, an aerial radiological survey of the ORR, city of Oak Ridge, and the surrounding area was conducted using parameters identical to those used during the 1980 survey (Maurer 1992).

Most recently, an aerial radiological survey of the ORR and surrounding area in Oak Ridge, which encompasses BCV, was conducted during the period March 30 to April 14, 1992 (Maurer 1993). The survey consisted of a series of parallel flight lines $76 \mathrm{~m}(250 \mathrm{ft})$ apart at 
an altitude of $46 \mathrm{~m}$ ( $150 \mathrm{ft})$. The survey was conducted by a helicopter flying at a speed of 70 knots. In support of aerial measurements, ground-based exposure rates and soil samples were obtained from seven "benchmark" sites located within the survey area. The groundbased measurements were used to verify the integrity of the aerial measurements. Radionuclide assays of representative soil samples were also performed to determine corresponding radioisotopic concentrations. In addition, high-altitude aerial photographs were obtained for use as base maps for the aerial contour data, and oblique aerial photographs were obtained for site documentation.

Two methods were used to analyze the aerial radiation data. The first was the gross count rate method, used to determine the ground level exposure rates. The second was the spectral window method, used to determine the man-made radioactivity and the photopeak count rates for specific man-made radionuclides (Maurer 1993). Radionuclides without gamma or strong X-rays, such as transuranics, will not be detected by the aerial survey; however, radiochemical analyses performed during the recent $R I$ of EFPC indicate these radionuclides are not a problem for ingestion pathways. Typical background exposure rates varied from 7 to $11 \mu \mathrm{R} / \mathrm{h}$ (including the estimated cosmic ray contribution of $3.8 \mu \mathrm{R} / \mathrm{h}$ ). The results of the aerial and ground-based measurements were found to vary by as much as $\pm 30 \%$.

Terrestrial exposure rates at $1 \mathrm{~m}$ above ground level were deduced from aerial measurements, integrated with the corresponding aircraft position coordinates, and compiled to produce a contour map (Fig. 3.58). These contours were superimposed on the high-altitude aerial photographs. The data for BCV are presented in Maurer (1992b). Total terrestrial gamma exposure rates for $\mathrm{BCV}$ at $1 \mathrm{~m}$ range from $<8$ to $60 \mu \mathrm{R} / \mathrm{h}$, with the overwhelming majority of readings being $<13 \mu \mathrm{R} / \mathrm{h}$. One site within $\mathrm{BCV}$ was identified with rates between 20 and $60 \mu \mathrm{R} / \mathrm{h}$. This site corresponds to the Bear Creek Burial Ground, a shallow disposal area for uranium metal tailings. Readings in the vicinity of BCV OU 2 show exposure rates between 8 and $13 \mu \mathrm{R} / \mathrm{h}$, but these readings are not statistically significant, as exposure rates $<10 \mu \mathrm{R} / \mathrm{h}$ above background rates ( 7 to $11 \mu \mathrm{R} / \mathrm{h}$ within the Oak Ridge area including the cosmic ray contribution of $3.8 \mu \mathrm{R} / \mathrm{h}$ ) are considered of no concern, and the correlations between aerial and ground-based measurements vary by as much as $\pm 30 \%$.

The man-made gross count (MMGC) rate for the BCV sites is shown in Maurer (1992b). There is a slightly elevated (1000-3200 counts per second) area in the vicinity of SL-1 and the HCDA. A Region of Interest (ROI 25) was identified at the above mentioned Burial Ground, with MMGC between 1000 and 100,000 counts per second (Fig. 3.59). The gamma spectrum for ROI 25 showed photopeaks for ${ }^{234 \mathrm{~m}} \mathrm{~Pa}$ (Fig. 3.60), which indicate the presence of ${ }^{238} \mathrm{U}$. This is not unexpected due to the nature of the material (uranium tailings) deposited in this area. The SL-1, HCDA, and Burial Ground areas will be investigated further in the RI for $\mathrm{BCV}$ OU 1 . There is no evidence of radioactivity produced by man-made radionuclides in the BCV OU 2 areas.

\subsection{DATA QUALITY REPORT}

\subsubsection{Purpose}

The purpose of this section is to provide an assessment of the QA/QC results from the BCV OU 2 RI to confirm that the data used in this report meet the data objectives established for this investigation. This will be accomplished through an evaluation of the 
Historic Preservation to ensure that there will be no adverse impacts to cultural resources. Should adverse impacts be anticipated, the three agencies will negotiate a Memorandum of Agreement before the remediation action proceeds.

\subsubsection{Rare, Threatened, or Endangered Species}

Although there are a number of state- and federally listed plant and animal species present or potentially present on the ORR, currently there are none present at the BCV OU 2 site that would be impacted by any potential remedial activities. Table 2.9 in Chap. 2 of this document has been extensively updated using 1993 and 1994 references to reflect those plant and animal species potentially occurring on the ORR. The table also indicates, for each plant and animal species potentially occurring on the ORR, the federal and/or state listed status of the plant or animal species.

\subsection{ACTION-SPECIFIC ARARs}

Performance, design, or other action-specific requirements set controls or restrictions on particular kinds of activities related to the management of hazardous waste (52 FR 32496). Selecting a particular remedial action at a site will invoke the appropriate action-specific ARARs that may specify particular performance standards or technologies, as well as specific environmental levels for discharged or residual chemicals. Action-specific ARARs for $\mathrm{BCV}$ OU 2 will be developed during selection of remedial alternatives in the FS. 


\section{REFERENCES}

Aihara, J. 1992. "Why aromatic compounds are stable." Sci. Amer., March.

Aliyev, A. T. and K. P. Kashkin. 1973. "Blood plasma esterases of tundra voles (microtus oeconomus) living under conditions of an increased natural background radiation (in Russian)," Radiobiologiya 13(4): 598. Translation: AEC-tr-7499, U.S. Atomic Energy Commission, Washington, D.C. (cited in Whicker and Schultz 1982).

Aliyev, A. T. and P. A. Korzhuev. 1973. "Amino acid composition of blood plasma proteins of root voles (microtus oeconomus pall.), living under various ecological conditions (in Russian)," Radiobiologiya 13(6): 818. Translation: AEC-tr-7534, U.S. Atomic Energy Commission, Washington, D.C. (cited in Whicker and Schultz 1982).

Aliyev, A. T., P. A. Korzhuev, and K. P. Kashkin. 1972. "Blood plasma proteins of the tundra vole microtus oeconomus, living under conditions of increased natural background (in Russian)," Radiobiologiya 12(1): 63. Translation: AEC-tr-7316, U.S. Atomic Energy Commission, Washington, D.C. (cited in Whicker and Schultz 1982).

Altshuller, A. P. and R. A. Linthurst. (eds). 1983. The acidic deposition phenomenon and its effects, Vol. II: Effects sciences, EPA/600/8-83/016B, U.S. Environmental Protection Agency, Washington, D.C.

Amdur, M. O., J. Doull, and C. D. Klassan. 1991. Casarett and Doull's: Taxicology, the basic science of poisons. 4th ed., Pergamon Press, New York.

AQUIRE (Aquatic Information Retrieval). 1992. Chemical Information Systems, Inc., Baltimore, Maryland., on line September 4.

Arena, J. M. 1974. Poisoning: Toxicology, symptoms, and treatments. Charles C. ThomasPublisher. Springfield, Illinois.

ATSDR (Agency for Toxic Substances and Disease Registry). 1988a. Toxicological profile for beryllium. U.S. Department of Health and Human Services. Public Health Service. Atlanta, Georgia.

ATSDR (Agency for Toxic Substances and Disease Registry). 1988b. Toxicity profile for lead. U.S. Department of Health and Human Services. Public Health Service. Atlanta, Georgia.

ATSDR (Agency for Toxic Substances and Disease Registry). 1989a. Toxicological profile for arsenic. U.S. Department of Health and Human Services. Public Health Service. Atlanta, Georgia.

ATSDR (Agency for Toxic Substances and Disease Registry). 1989b. Toxicological profile for plutonium. U.S. Department of Health ant Human Services. Public Health Service. Atlanta, Georgia. 
ATSDR (Agency for Toxic Substances and Disease Registry). 1989c. Toxicological profile for uranium. U.S. Department of Health and Human Services. Public Health Service. Atlanta, Georgia.

ATSDR (Agency for Toxic Substances and Disease Registry): 1987-1990. U.S. Department of Health and Human Services. Public Health Services. Atlanta, Georgia.

ATSDR (Agency for Toxic Substances and Disease Registry). 1990a. Toxicological profile for manganese. U.S. Department of Health and Human Services. Public Health Service. Atlanta, Georgia.

ATSDR (Agency for Toxic Substances and Disease Registry). 1990b. Toxicological profile for thorium. TP-90-25. United States Department of Health \& Human Services. Public Health Service. Atlanta, Georgia.

ATSDR (Agency for Toxic Substances and Disease Registry). 1993a. Toxicological profile for polychlorinated biphenyls. U.S. Department of Health \& Human Services. Public Health Service. April.

ATSDR (Agency for Toxic Substances and Disease Registry). 1993b. Taxicological profile for tetrachloroethylene. U.S. Department of Health \& Human Services. Public Health Service, April.

ATSDR (Agency for Toxic Substances and Disease Registry). 1993c. Toxicological profile for methylene chloride. U.S. Department of Health \& Human Services. Public Health Service. April.

Baes, C. F. et al. 1984. A review of analysis of parameters for assessing transport of environmentally released radionuclides through agriculture. ORNL-5786, Martin Marietta Energy Systems, Inc., Oak Ridge National Laboratory, Oak Ridge, Tennessee.

Bailey, Z. C. and R. W. Lee. 1991. Hydrogeology and geochemistry in Bear Creek and Union valleys, near Oak Ridge, Tennessee. U.S. Geological Survey Water-Resources Investigations Report, 90-4008, Nashville, Tennessee.

Barnthouse, L. W. et al. 1986. User's manual for ecological risk assessment. Publication no. 2679, ORNL-6251, Environmental Sciences Division, Martin Marietta Energy Systems, Inc., Oak Ridge National Laboratory, Oak Ridge, Tennessee.

Battelle. 1989a. RCRA facility investigation plan, Rust Spoil Area (d-106). Y/TS-354R1, Oak Ridge Y-12 Plant, Oak Ridge, Tennessee, May.

Battelle. 1989b. RCRA facility investigation plan, Spoil Area 1 (d-107). Y/TS-363R1, Oak Ridge Y-12 Plant, Oak Ridge, Tennessee, June.

BEIAS (Biomedical and Environmental Information Analysis Section). 1993. Toxicity profiles for contaminants of concern on the Oak Ridge Reservation. (ES/ER/TM-77). Martin Marietta Energy Systems, Oak Ridge, Tennessee. 
BEIR III (Biological Effects of Ionizing Radiation). 1980. National Academy of Sciences Biological Effects of Ionizing Radiation Committee.

BNI (Bechtel National, Inc.). 1983. Preliminary characterization and remedial action plan for the Y-12 Plant Oil Landfarm. Y/Sub/83-47974C/1, Oak Ridge Y-12 Plant, Oak Ridge, Tennessee, October.

BNI. (Bechtel National, Inc.). 1984. Geologic and hydrogeologic data for Bear Creek Valley Burial Grounds $A$ and $B$. Y/Sub/84-47974C/2, Oak Ridge Y-12 Plant, Oak Ridge, Tennessee.

Bogle, M. A., R. R. Turner, and S. D. Easterling. 1991. Characterization of contamination along the upper reaches of the east fork of Tributary 8 at Burial Ground C in Bear Creek Valley. Y/TS-720, Martin Marietta Energy Systems, Inc., Oak Ridge, Tennessee, February.

Bohn, H. L., B. L. McNeal, and G. A. O'Conner. 1985. Soil chemistry. 2nd ed., John Wiley and Sons, New York, $341 \mathrm{pp}$.

Bonazountas, M. and J. Wagner. 1984. Sesoil: A seasonal soil compartment model. Arthur D. Little, Inc., Cambridge, Massachusetts, prepared for U.S. Environmental Protection Agency, Office of Toxic Substances.

Bonazountas, M., J. Wagner, and B. Goodwin. 1982. Evaluation of seasonal soil/groundwater pollutant pathways. U.S. Environmental Protection Agency contract no. 68-01-5949 (9), Arthur D. Little, Inc., Cambridge, Massachusetts.

Bradburn, D. M. and E. H. Rosenbalm. 1984. Resource management plan for the U.S. Department of Energy Oak Ridge Reservation, Appendix 6: Forest management. ORNL/6026-V6, Martin Marietta Energy Systems, Inc., Oak Ridge National Laboratory, Oak Ridge, Tennessee.

Budavari, S. et al., (eds). 1989. The Merck index: An encyclopedia of chemicals, drugs, and biologicals. 11th 3e. Merck and Co., Inc., Rahway, New Jersey.

Callahan, M. A. et al. 1979. Water-relator environmental fate of 129 priority pollutants, Vol. I: introduction and technical background, metals, and inorganics, pesticides and PCBs. EPA/440/4-79/029A, U.S. Environmental Protection Agency, Washington, D.C.

Casarett, A. P. 1968. Radiation biology. Prentice-Hall, Inc., Englewood Cliffs, New Jersey.

Cunningham, M. and L. Pounds. 1991. Resource management plan for the Oak Ridge Reservation: Wetlands on the Oak Ridge Reservation (V.28). ORNL/NERP-5/V28, Martin Marietta Energy Systems, Inc., Oak Ridge National Laboratory, Oak Ridge, Tennessee.

Cunningham, M., L. Pounds, and S. Oberholster. 1993. Resource management plan for the Oak Ridge Reservation. Volume 29: Rare plants on the Oak Ridge Reservation. ORNL/NERP-7ESD-4054. 
deLaguna, W. et al. 1963. Engineering development of hydraulic fracturing as a method for permanent disposal of radioactive wastes. ORNL/4259, Martin Marietta Energy Systems, Inc., Oak Ridge National Laboratory, Oak Ridge, Tennessee.

DOE (U.S. Department of Energy). 1980. Oak Ridge Reservation land-use plan. Rev. 1, DOE/ORO-748, Oak Ridge Operations Office, Oak Ridge, Tennessee, March.

DOE (U.S. Department of Energy). 1982. Environmental assessment, Y-12 Plant site, Oak Ridge, Tennessee, DOE/EA-0182.

DOE (U.S. Department of Energy). 1993. Final report on the background soil characterization project at the Oak Ridge Reservation, Oak Ridge, Tennessee. DOE/OR/01-1175, ES/ER/TM-84, Martin Marietta Energy Systems, Inc., Oak Ridge, Tennessee.

Domenico, P. A. and F. W. Schwartz. 1990. Physical and chemical hydrogeology, John Wiley and Sons, New York.

Dreier, R. B., D. K. Solomon, and C. M. Beaudoin. 1987. "Fracture characterization in the unsaturated zone of a shallow land burial facility," in Flow and transport through fractured rock. American Geophysical Union Monograph. 42: 51-59.

Droppo, J. G. et al. 1989. Multimedia environmental pollutant assessment system (MEPAS) application guidance. Pacific Northwest Laboratory, operated for the U. S. Department of Energy by Battelle Memorial Institute, PNL-7216, Vol. 2, December, p. 2.5.

DuBuchanne, G. D. and R. M. Richardson. 1956. Groundwater resources of East Tennessee. Bulletin 58, Part I, Division of Geology, State of Tennessee Department of Conservation.

Dunne, L. J. 1990. Nutrition almanac. Third Edition. Nutrition Search, Inc., John D. Kirschmann, Director. McGraw Hill Publishing Company.

Energy Systems (Martin Marietta Energy Systems, Inc.). 1984a. Preliminary assessment of existing contamination in Bear Creek Valley watershed area and potential remedial actions for mitigating its impact on Bear Creek. Y/TS-51/1, Oak Ridge Y-12 Plant, Oak Ridge, Tennessee.

Energy Systems (Martin Marietta Energy Systems, Inc.). 1984b. Appendices: Preliminary assessment of existing contamination in Bear Creek Valley watershed area and potential remedial actions for mitigating its impact on Bear Creek, Y/TS-51-2, Oak Ridge Y-12 Plant, Oak Ridge, Tennessee.

Energy Systems (Martin Marietta Energy Systems, Inc.). 1988. Revised RCRA closure plan for the S-3 Ponds. Y/TS-393, Oak Ridge Y-12 Plant, Oak Ridge, Tennessee, February.

Energy Systems (Martin Marietta Energy Systems, Inc.). 1989. RCRA facility investigation plan for the SY-200 Yard. Y/TS-598, Oak Ridge Y-12 Plant, Oak Ridge, Tennessee.

Energy Systems (Martin Marietta Energy Systems, Inc.). 1990. Clinch River RCRA facility investigation plan. ES/ER-1/D1, Martin Marietta Energy Systems, Inc., Oak Ridge, Tennessee, March. 
Energy Systems (Martin Marietta Energy Systems, Inc.). 1991a. Oak Ridge Reservation environmental report for 1990. ES/ESH-18/V1\&V2, Martin Marietta Energy Systems, Inc., Oak Ridge, Tennessee, September.

Energy Systems (Martin Marietta Energy Systems, Inc.). 1991b. Environmental Restoration Division quality assurance program plan. ES/ER/TM-4/R1, Martin Marietta Energy Systems, Inc., Oak Ridge, Tennessee, September.

Energy Systems (Martin Marietta Energy Systems, Inc.). 1992. Oak Ridge Reservation Site Management Plan for the Environmental Restoration Program. DOE/OR/01-1001/R2, Environmental Restoration Division, Martin Marietta Energy Systems, Oak Ridge, Tennessee, June.

Energy Systems (Martin Marietta Energy Systems, Inc.). 1993a. Oak Ridge Reservation environmental report for 1992. ES/ESH-31/V1\&V2, Martin Marietta Energy Systems, Inc., Oak Ridge, Tennessee, September.

Energy Systems (Martin Marietta Energy Systems, Inc.). 1993b. Annotated outlines for documents required by FFA and CERCLA for Oak Ridge Reservation sites. (DOE/OR/011077). Oak Ridge, Tennessee.

Engelder, T. 1985. "Loading paths to joint propagation during a tectonic cycle: An example from the Appalachian plateau, U.S.A." J. Structural Geol. 7(3/4): 459-476.

EPA (U.S. Environmental Protection Agency). 1976. Quality criteria for water. EPA/440/9-76/023, Washington, D.C.

EPA (U.S. Environmental Protection Agency). 1977. Investigation of selected potential environmental containments halogenated benzenes. Washington, D.C., July.

EPA (U.S. Environmental Protection Agency). 1980a. Interim guidelines and specifications for preparing quality assurance project plans. QAMS 005/80, Washington, D.C.

EPA (U.S. Environmental Protection Agency). 1980b. Ambient water quality criteria for phthalate esters. EPA-440/5-80-067. October.

EPA (U.S. Environmental Protection Agency). 1982. An exposure and risk assessment for benzo(a)pyrene and other polyaromatic hydrocarbons. Vols I-III, Washington, D.C., October.

EPA (U.S. Environmental Protection Agency). 1983. Methods for chemical analysis of water and wastes. EPA/600/4-79/020, March.

EPA (U.S. Environmental Protection Agency). 1986. Test methods for evaluating solid waste, physical/chemical methods. 3rd ed., EPA SW-846.

EPA (U.S. Environmental Protection Agency). 1987a. Hazardous waste treatment, storage, and disposal facilities (TSDF)-air emission models. Office of Air and Radiation, Research Triangle Park, North Carolina. 
EPA (U.S. Environmental Protection Agency). 1987b. Health assessment document for vanadium and compounds. Office of Health and Environmental Assessment, Environmental Criteria and Assessment Office. Cincinnati, Ohio. ECAO-CINN-H108.

EPA (U.S. Environmental Protection Agency). 1988a. Superfund exposure assessment manual. EPA/540/1-88/001, Office of Remedial Response, Washington D.C.

EPA (U.S. Environmental Protection Agency). 1988b. CERCLA compliance with other laws manual, draft guidance. Vol. I. OSWER Directive 9234.1-01, EPA Office of Emergency and Remedial Response, Washington, D.C.

EPA. (U.S. Environmental Protection Agency). 1988c. Guidance for conducting remedial investigations and feasibility studies under CERCLA. EPA/540/G-88/004, Office of Solid Waste and Emergency Response, OSWER Directive 9335.3-01.

EPA (U.S. Environmental Protection Agency). 1989a. Exposure factors handbook. EPA/600/889/043. Office of Health and Environmental Assessment, Washington, D.C.

EPA (U.S. Environmental Protection Agency). 1989b. Risk assessment guidance for Superfund Volume I, human health evaluation manual (Part A), interim final. EPA/540/1-89/002, Office of Emergency and Remedial Response.

EPA (U.S. Environmental Protection Agency). 1989c. Risk assessment guidance for Superfund, Vol. II, environmental evaluation manual, interim final. EPA/540/1-89/001, Office of Solid Waste and Emergency Response, Washington, D.C.

EPA (U.S. Environmental Protection Agency). 1989d. Ecological assessments of hazardous waste sites: $A$ field and laboratory reference document. EPA/600/3-89/0113, Washington, D.C.

EPA (U.S. Environmental Protection Agency). 1990a. Guidance on remedial actions for Superfund sites with PCB contamination. OSWER Directive 9355.4-01, EPA Office of Emergency Remedial Response, Washington, D.C., August.

EPA (U.S. Environmental Protection Agency). 1990b. Contract laboratory program statement of work for inorganic analysis. ILM02.0.

EPA (U.S. Environmental Protection Agency). 1990c. Contract laboratory program statement of work for organic analysis, OLM01.8.

EPA (U.S. Environmental Protection Agency). 1991a. Integrated risk information system (IRIS). EPA/600/8-86/032a, Office of Health and Environmental Assessment, Cincinnati, Ohio.

EPA (U.S. Environmental Protection Agency). 1991b. Health effects assessment summary tables (HEAST), first quarter, FY 1991. OERR 9200.6-303-(91-1), Office of Emergency and Remedial Response, Washington, D.C. 
EPA (U.S. Environmental Protection Agency). 1991c. Risk assessment guidance for Superfund: Volume I-Human health evaluation manual (Part B), development of risk-based preliminary remediation goals. 9285.7-01B, Office of Emergency and Remedial Response, Washington, D.C.

EPA (U.S. Environmental Protection Agency). 1991d. Soil transport and fate (STF) database and model management system. Ver. 2.0, R.S. Kerr Environmental Research Laboratory, Ada, Oklahoma.

EPA (U.S. Environmental Protection Agency). 1991e. Ecological assessment of Superfund sites: An overview. ECOUpdate 1(2), Office of Solid Waste and Emergency Response, Publ. 9345.0-05I.

EPA (U.S. Environmental Protection Agency). 1991f. Human health evaluation manual, supplemental guidance: Standard default exposure factors. Office of Solid Waste and Emergency Response, OSWER Directive 9285.6-03.

EPA (U.S. Environmental Protection Agency). 1991g. Role of the baseline risk assessment in Superfund remedy selection decisions. (OSWER Directive 9355.0-30). Office of Solid Waste and Emergency Response, Washington, D.C.

EPA (U.S. Environmental Protection Agency). 1991h. Test methods for evaluating solid waste. SW-846, 3rd Edition. Washington, D.C.

EPA (U.S. Environmental Protection Agency). 1992a. Dermal exposure assessment: principles and applications. Interim report EPA/600/8-91/011B. Washington, D.C.

EPA (U.S. Environmental Protection Agency). 1992b. Supplemental guidance to RAGS: Calculating the concentration term. Intermittent Bulletin (9285-7-081). Office of Solid Waste and Emergency Response. Washington, D.C.

EPA (U.S. Environmental Protection Agency). 1992c. Framework for ecological risk assessment, Washington, D.C.

EPA (U.S. Environmental Protection Agency). 1992d. Health effects assessment summary tables (HEAST), FY 1991. OERR 9200, 6363, Office of Emergency and Remedial Response, Washington, D.C.

EPA (U.S. Environmental Protection Agency). 1992e. Integrated risk information system (IRIS). Office of Health and Environmental Criteria and Assessment Office, Cincinnati, Ohio.

EPA (U.S. Environmental Protection Agency). 1993a. Risk reduction engineering laboratory (RREL) treatability database. Ver. 4.0, Office of Research and Development, Cincinnati, Ohio.

EPA (U.S. Environmental Protection Agency). 1993b. Henlth effects assessment summary tables. FY 1993 annual. OHEA ECAO-CIN-999, E A Office of Emergency and Remedial Response, Washington, D.C. 
EPA (U.S. Environmental Protection Agency). 1993c. Provisional guidance for quantitative risk assessment of polycyclic aromatic hydrocarbons. Office of Research and Development. Washington, D.C., July.

EPA (U.S. Environmental Protection Agency). 1994a. Integrated risk information system database. Office of Research and Development. Washington, D.C.

EPA (U.S. Environmental Protection Agency). 1994b. Wildlife exposure factors handbook. EPA/600/R-93/187A,B, Office of Health and Environmental Assessment, EPA, Washington, D.C.

ERDA (Energy Research and Development Administration). 1975. Preliminary draft environmental analysis Oak Ridge Operations. Vol. VI. This draft can't be cited.

Follet, R. H., L. S. Murphy, and R. L. Donahue. 1981. Fertilizers and soil amendments. Prentice-Hall, Englewood Cliffs, New Jersey.

Foreman, J. L. et al. 1991. "Slope and basinal carbonate deposition in the nolichucky shale (Upper Cambrian), East Tennessee: Effect of carbonate suppression by siliciclastic deposition on basin-margin morphology," in Mixed carbonates-Siliciclastic sequences. SEPM Core Workshop, no. 15, Dallas, Texas.

Freeze, R. A. and J. A. Cherry. 1979. Groundwater. Prentice-Hall, New York.

Friberg, L., Nordberg, G. and Vouk, V. 1986. Handbook on the toxicology of metals, 2nd edition. Elsevier Sciences Publishers, Amsterdam.

Garrison, R. H., Jr. and E. Somer. 1985. The nutrition desk reference. Keats Publishing, Inc. New Canaan, Connecticut.

Geraghty and Miller. 1985. Remedial alternatives for the Bear Creek Valley waste disposal area. Y/Sub/85-00206C/3, Martin Marietta Energy Systems, Inc., Oak Ridge Y-12 Plant, Oak Ridge, Tennessee.

Geraghty and Miller. 1986. Aquifer-test data and design of recovery wells, S-3 Ponds. Y/Sub/86$00206 \mathrm{C} / 2$, Martin Marietta Energy Systems, Inc., Oak Ridge Y-12 Plant, Oak Ridge, Tennessee.

Geraghty and Miller. 1987. Hydrogeologic investigation of the S-3 Pond Area at the Y-12 Plant. Y/Sub/87-00206C/18, Martin Marietta Energy Systems, Inc., Oak Ridge Y-12 Plant, Oak Ridge, Tennessee.

Geraghty and Miller. 1988. Groundwater quality assessment for the S-3 Ponds hazardous waste disposal unit at the Y-12 Plant, 1987. Y/Sub/88-00206C/1, Martin Marietta Energy Systems, Inc., Oak Ridge Y-12 Plant, Oak Ridge, Tennessee.

Geraghty and Miller. 1989a. Tracer study of the hydrologic system of Upper Bear Creek, Y-12 Plant, Oak Ridge, Tennessee. Y/Sub/89-00206C/4, Martin Marietta Energy Systems, Inc., Oak Ridge Y-12 Plant, Oak Ridge, Tennessee. 
Geraghty and Miller. 1989b. Groundwater quality assessment for the $S$-3 Ponds waste management area at the Y-12 Plant, 1988. Y/Sub/89-00206C/7, Martin Marietta Energy Systems, Inc., Oak Ridge Y-12 Plant, Oak Ridge, Tennessee.

Geraghty and Miller. 1989c. Groundwater quality assessment for the Oil Landfarm waste management area at the Y-12 Plant, 1988. Y/Sub/89-00206C/8, Martin Marietta Energy Systems, Inc., Oak Ridge Y-12 Plant, Oak Ridge, Tennessee.

Geraghty and Miller. 1990. Comprehensive groundwater monitoring plan for the Department of Energy Y-12 Plant, Oak Ridge, Tennessee. Y/Sub/90-00206C/5, Martin Marietta Energy Systems, Inc., Oak Ridge Y-12 Plant, Oak Ridge, Tennessee, September.

Gruneberg, H. 1964. "Genetical research in an area of high natural radioactivity in South India." Nature 204: 222.

Haase, C. S., E. C. Walls, and C. D. Farmer. 1985. Structural and stratigraphic data for the Conasauga Group and Rome Formation on the Copper Creek thrust sheet near Oak Ridge, Tennessee: Preliminary data from test borehole ORNL-Joy No. 2. ORNL/TM-9159, Martin Marietta Energy Systems, Inc., Oak Ridge National Laboratory, Oak Ridge, Tennessee.

Haith, D. A. 1980. "A mathematical model for estimating pesticides losses in runoff." Jour. of Environ. Qual. 9(3): 428-433.

Hammonds, J. A. and Hoffman. 1992. Toxicity profiles for radionuclides. SENES Oak Ridge, Inc., Center for Risk Analysis, Oak Ridge, Tennessee.

Hardy, C., L. Pounds, and R. Cook. 1992. Results of the Y-12 Area rare plant and wetland survey. Martin Marietta Energy Systems, Inc., Oak Ridge National Laboratory, Oak Ridge, Tennessee.

Harkness, J. E. and J. E. Wagner. 1989. The biology and medicine of rabbits and rodents. Lea and Febiger.

Hatcher, R. D. Jr. et al. 1992. Status report: The geology of the Oak Ridge Reservation. Environmental Sciences Division, Publ. no. 3860, ORNL/TM-12074, Martin Marietta Energy Systems, Inc., Oak Ridge National Laboratory, Oak Ridge, Tennessee, October.

Heiserman, D. L. 1992. Exploring chemical elements and their compounds. TAB Books, Division of McGraw-Hill, Inc.

Hem, J. D. and C. E. Roberson. 1967. Form and stability of aluminum hydroxide complexes in dilute solution, USGS Water-Sup. Pap. 1827-A, pp. 55.

Herbes, S. E. 1988. PCB contamination in the sediments of the oil retention ponds and associated tributary channels at the Burial Grounds of the Oak Ridge Y-12 Plant. Y/TS-431, Martin Marietta Energy Systems, Inc., Oak Ridge, Tennessee.

Hetrick, D. M. 1984. Simulation of hydrologic cycle for watersheds. Presented at Ninth IASTED International Conference on Energy, Power and Environmental Systems, San Francisco, California. 
Hetrick, D. M. and S. J. Scott. 1993. The new SESOIL user's guide. Wisconsin Department of Natural Resources, PUBL-SW-200, Madison, Wisconsin.

Hetrick, D. M. and C. C. Travis. 1988. Model predictions of watershed erosion components. Water Resources Bulletin, pp. 413-419.

Hetrick, D. M., R. J. Luxmoore, and M. L. Tharp. 1993. Latin hypercube sampling with the SESOIL model proceedings. Eighth Annual Conference on "Contaminated Soils," University of Massachusetts at Amherst, September.

Hetrick, D. M. et al. 1986. Model predictions of watershed hydrologic components: comparison and verification. Water Resources Bulletin, pp. 803-810.

Hetrick, D. M. et al. 1989. Qualitative validation of pollutant transport components of an unsaturated soil zone model (SESOIL). ORNL/TM-10672, Martin Marietta Energy Systems, Inc., Oak Ridge National Laboratory, Oak Ridge, Tennessee.

HEW (U.S. Department of Health, Education, and Welfare). 1970. Radiological health handbook. Bureau of Radiological Health, Public Health Service, Rockville, Maryland.

Hoos, A. B. and Z. C. Bailey. 1986. Reconnaissance of surficial geology, regolith thickness, and configuration of the bedrock surface in Bear Creek and Union valleys, near Oak Ridge, Tennessee. Water Resources Investigations Report 86-4165, U.S. Geological Survey.

Howard, P. H. et al. 1991. Handbook of environmental degradation rates. Lewis Publishers, Inc., Chelsea, Michigan.

HSEAD (Health, Safety, Environment, and Accountability Division). 1984a. Preliminary assessment of existing contamination in Bear Creek Valley watershed area and potential remedial actions for mitigating its impact on Bear Creek. Y/TS-51/1, Y-12 Plant, Oak Ridge, Tennessee.

HSEAD (Health, Safety, Environment, and Accountability Division). 1984b. Appendices: Preliminary assessment of existing contamination in Bear Creek Valley watershed area and potential remedial actions for mitigating its impact on Bear Creek. Y/TS-51/2, Y/12 Plant, Oak Ridge, Tennessee.

HSEAD (Health, Safety, Environment, and Accountability Division). 1987a. Post-closure permit application for the S-3 Ponds hazardous-waste disposal unit at the Y-12 Plant. Y/TS-51/2. Y-12 Plant, Oak Ridge, Tennessee.

HSW (HSW Environmental Consultants, Inc.). 1991. Groundwater quality assessment for the Bear Creek hydrogeologic regime at the Y-12 Plant, 1990: Data interpretation and proposed modifications for 1991. Y/SUB/91-YP507C/P1\&P2, Martin Marietta Energy Systems, Inc., Oak Ridge Y-12 Plant, Oak Ridge, Tennessee. 
HSW (HSW Environmental Consultants, Inc.). 1992. Groundwater quality assessment for the Bear Creek hydrogeologic regime at the Y-12 Plant: 1991 groundwater quality data interpretations and proposed program modifications. Y/Sub/92-YP507C/1/P1\&P2, Martin Marietta Energy Systems, Inc., Oak Ridge Y-2 Plant, Oak Ridge, Tennessee, August.

HSW (HSW Environmental Consultants, Inc.). 1993. Groundwater quality assessment for the Bear Creek hydrogeologic regime at the Y-12 Plant: 1992 groundwater quality data interpretations and proposed program modifications. Y/Sub/93-YP507C/1/P1\&P2, Martin Marietta Energy Systems, Inc., Oak Ridge Y-2 Plant, Oak Ridge, Tennessee, September.

Hull, R. N. and G. W. Suter, II. 1992. Toxicological benchmarks for screening potential contaminants of concern for effects on sediment-associated biota. ORNL/ER-177, ES/ER/TM-95, Martin Marietta Energy Systems, Inc., Oak Ridge National Laboratory, Oak Ridge, Tennessee.

ICRP (International Commission on Radiological Protection). 1991. 1990 recommendations of the international commission on radiological protection. ICRP Publication no. 60. Pergamon Press, Inc. New York.

Javandel, I., C. Doughty, and C. F. Tsang. 1984. "Groundwater transport: Handbook of mathematical models." American Geophysical Union Water Resources Monograph Series 10, Washington, D.C.

Johnson, R. M. 1964. Herpetofauna of the Oak Ridge area. ORNL/3653, Martin Marietta Energy Systems, Inc., Oak Ridge National Laboratory, Oak Ridge, Tennessee.

Killough, G. G. and K. F. Eckerman. 1983. "Internal Dosimetry" in: Radiological assessment. NUREG/CR-3332, ORNL-5966, pp.7-1 to 7-98. Eds. J. E. Till and H. R. Meyer. U.S. Nuclear Regulatory Commission. Washington, D.C.

Kimbrough, C. W., L. W. Long, and L. W. McMahon. 1990. Environmental surveillance procedures quality control program. (ESH/Sub/87-21706/1), Rev. 1, Martin Marietta Energy Systems, Inc., Oak Ridge, Tennessee.

King, H. L. and C. S. Haase. 1987. Subsurface-controlled geological maps for the Y-12 Plant and adjacent areas of Bear Creek Valley. ORNL/TM-10112, Martin Marietta Energy Systems, Inc., Oak Ridge National Laboratory, Oak Ridge, Tennessee.

Klassen, C. D., M. O. Amdur, and J. Doull. 1986. Casarett and Doull's toxicology: The basic science of poisons, 3rd Ed. Macmillan Publishing Company. New York.

Knight, M. J. 1983. Uptake by plants of radionuclides from FUSRAP waste materials. ANL/EIS-10, prepared by Argonne National Laboratory, Argonne, Illinois, for U.S. Department of Energy, Oak Ridge Operations Office, Oak Ridge, Tennessee.

Kroodsma, R. L. 1987. Resource management plan for the Oak Ridge Reservation, Volume 24: Threatened and endangered animal species. ORNL/ESH-1/V24, Martin Marietta Energy Systems, Inc., Oak Ridge National Laboratory, Oak Ridge, Tennessee, January. 
Kroodsma, R. L. 1994. Personal communication to R. E. Ambrose, Science Applications International Corporation (SAIC).

Law (Law Engineering Testing Company). 1975. Preliminary safety analysis report for nuclear fuel recovery and recycling center. Prepared for the Exxon Nuclear Company.

Law (Law Engineering Testing Company). 1983. Results of groundwater monitoring studies: Oak Ridge Y-12 Plant. Y/Sub/83-47936/1, Oak Ridge Y-12 Plant, Oak Ridge, Tennessee, September.

Lee, R. R. and R. H. Ketelle. 1987. Stratigraphic influence on deep groundwater flow in the Knox Group Copper Ridge Dolomite on the west Chestnut Ridge site. ORNL/TM-10479, Martin Marietta Energy Systems, Inc., Oak Ridge National Laboratory, Oak Ridge, Tennessee.

Lee, R. R. and R. H. Ketelle. 1988. Subsurface geology of the Chickamauga Group at the Oak Ridge National Laboratory. ORNL/TM-10749, Martin Marietta Energy Systems, Inc., Oak Ridge National Laboratory, Oak Ridge, Tennessee.

Lietzke, D. A., S. Y. Lee, and R. E. Lambert. 1988. Soils, surficial geology, and geomorphology of the Bear Creek Valley low-level waste disposal development and demonstration program site. ORNL/TM-10543, Martin Marietta Energy Systems, Inc., Oak Ridge National Laboratory, Oak Ridge, Tennessee.

Long, E. R. and L. G. Morgan. 1990. The potential for biological effects of sediment-sorbed contaminants tested in the national status and trends program. National Oceanic and Atmospheric Administration Technical Memorandum NOS OMA \#52, Seattle, Washington.

Lowery, J. F. et al. 1986. Water resources data for Tennessee, water year 1985. Report USGS/WRG/HD-86/216, U.S. Geological Survey, Nashville, Tennessee.

Lowery, J. F. et al. 1987. Water resources data for Tennessee, water year 1986. Report USGS/WRG/HD-86/216, U.S. Geological Survey, Nashville, Tennessee.

Lowery, J. F. et al. 1988. Water resources data for Tennessee, water year 1988. Water Data Report TN-88-1, U.S. Geological Survey, Nashville, Tennessee.

Lutz, C. T. and R. B. Dreier. 1988. "Differences in local deformation history as indicated by fracture orientations in two foreland thrust sheets." Geol. Soc. Am. Abstracts with Program 20(7).

Maurer, R. J. 1992. An aerial radiological survey of the Oak Ridge Reservation and surrounding area. EGG-10617-1123, EG\&G Energy Measurements, Oak Ridge, Tennessee, April.

Maurer, R. J. 1993. An aerial radiological survey of the Oak Ridge Reservation and surrounding area. EGG-10617-1129, EG\&G Energy Measurements, Oak Ridge, Tennessee, April. 
McCauley, L. L. 1985. Analytical results for water, sediment, and soil samples collected in the Y-12 Plant Bear Creek Valley waste disposal areas. Y/TS-112, Oak Ridge Y-12 Plant, Oak Ridge, Tennessee.

McMaster, W. M. 1967. Hydrologic data for the Oak Ridge Area, Tennessee. Water-Supply Paper no. 1838-N, U.S. Geological Survey, Washington, D.C.

Melancol, S. M., J. E. Pollard, and S. C. Hern. 1986. "Evaluation of SESOIL, PRZM, and PESTAN in a laboratory column leaching experiment." Environ. Toxicol. and Chemistry 5(10): 865-878.

Mericle, L. W. and R. P. Mericle. 1965. "Biological discrimination of differences in natural background radiation level," Radiat. Bot. 5(6): 475. (cited in Whicker and Schultz 1982).

Michigan Water Resources Commission. 1986. Part 4, rules, water quality standards. Lansing, Michigan.

Mills, W. B. et al. 1982. Water quality assessment: a screening procedure for toxic and conventional pollutants: Parts 1, 2, and 3. EPA-6001 6-82-004 a,b,c, EPA Environmental Research Laboratory, Office of Research and Development, Athens, Georgia.

Moore, G. K. 1988. Concepts of groundwater occurrence and flow near Oak Ridge National Laboratory, Tennessee. ORNL/TM-10969, Martin Marietta Energy Systems, Inc., Oak Ridge National Laboratory, Oak Ridge, Tennessee.

Moore, G. K. and L. E. Toran. 1992. Supplement to a hydrologic framework for the Oak Ridge Reservation, Oak Ridge, Tennessee. ORNL/TM-12191, Martin Marietta Energy Systems, Inc., Oak Ridge National Laboratory, Oak Ridge, Tennessee.

NCRP (National Council on Radiation Protection and Measurement). 1977. Environmental radiation measurements. NCRP Report no. 50. Washington, D.C.

NCRP (National Council on Radiation Protection and Measurement). 1985. Radiological assessment: Predicting the transport, bioaccumulation, and uptake by man of radionuclides released to the environment. NCRP Report no. 76, Bethesda, Maryland, May, p. 70.

NCRP (National Council on Radiation Protection and Measurement). 1989. Screening techniques for determining compliance with environmental standards. Releases of radionuclides to the atmosphere. January.

NCRP (National Council on Radiation Protection and Measurement). 1990. Effects of ionizing radiation on aquatic organisms. NCRP Report no. 109, Bethesda, Maryland.

NCRP (National Council on Radiation Protection and Measurements). 1993. Uncertainty in NCRP screening models relating to atmospheric transport, deposition, and uptake by humans. Bethesda, Maryland, NCRP Commentary no. 8, September, p. 17. 
Ng, Y. C., C. S. Colsher, and S. E. Thompson. 1982. Soil-to-plant concentration factors for radiological assessment. NUREG/CR-2975, UCID-19463, prepared for U.S. Nuclear Regulatory Commission, Washington, D.C., and prepared by Lawrence Livermore National Laboratory, Livermore, California, November.

NIOSH (National Institute for Occupational Safety and Health). 1992. RTECS (Registry of Toxic Effects of Chemical Substances), searched on line October.

NLM (National Library of Medicine). 1992. Hazardous substances data bank (HSDB). Toxicological Data Network (TOXNET), Bethesda, Maryland.

NOAA (National Oceanic and Atmospheric Administration). 1985. Local climatological data: Monthly summaries for 1985, Oak Ridge, Tennessee. National Climatic Data Center, Asheville, North Carolina.

NOAA (National Oceanic and Atmospheric Administration). 1986. Local climatological data: Monthly summaries for 1986, Oak Ridge, Tennessee. National Climatic Data Center, Asheville, North Carolina.

NOAA (National Oceanic and Atmospheric Administration). 1987. Local climatological data: Monthly summaries for 1987, Oak Ridge, Tennessee. National Climatic Data Center, Asheville, North Carolina.

NOAA (National Oceanic and Atmospheric Administration). 1993. Local climatological data: Annual summary with comparative data. National Climatic Data Center, Asheville, North Carolina.

Odum, E. P. 1971. Fundamentals of ecology. 3rd ed., W.B. Saunders, Philadelphia, Pennsylvania.

Opresko, D. M., B. E. Sample, and G. W. Suter. 1993. Toxicological benchmarks for wildlife. ES/ER/TM-86, Martin Marietta Energy Systems, Inc., Oak Ridge National Laboratory, Oak Ridge, Tennessee.

Owen, B. A. 1990. "Literature-derived absorption coefficients for 39 chemicals via oral and inhalation routes of exposure." Reg. Toxicol. and Pharm., Vol. 11, pp. 237-252.

Parr, P. D. 1984. Resource management plan for the Oak Ridge Reservation, Volume 4: Endangered and threatened plant species. ORNL/6026/V4, Martin Marietta Energy Systems, Inc., Oak Ridge National Laboratory, Oak Ridge, Tennessee.

Parr, P. D. and L. R. Pounds. 1987. Resource management plan for the Oak Ridge Reservation, Volume 23: Oak Ridge national environmental research park, research sites, and state natural areas. ORNL/ESH-1/V23, Martin Marietta Energy Systems, Inc., Oak Ridge National Laboratory, Oak Ridge, Tennessee, May.

Perkins, A. B. 1989. RCRA facility investigation plan, SY-200 Yard, Oak Ridge Y-12 Plant, Oak Ridge, Tennessee. Y/TS-598, Martin Marietta Energy Systems, Inc., Oak Ridge Y-12 Plant, December. 
Perry, R. H., C. H. Chilton, S. D. Kirkpatrick. 1969. Chemical engineers handbook. Mc-Graw Hill Book Company, New York.

Petrich, C. H. et al. 1984. Resource management plan for the U.S. Department of Energy Oak Ridge Reservation. Appendix G: Geography, demography, topography, and soils. ORNL/6020/V7, Martin Marietta Energy Systems, Inc., Oak Ridge National Laboratory, Oak Ridge, Tennessee.

Pulliam, Pamela J. 1985. Water-quality data for 34 sites, April and June 1984, near the Y-12 Plant. The Oak Ridge Reservation, Tennessee. Open File Report 85-553, U.S. Geological Survey.

Radian (Radian Corp.). 1993. Y-12 Plant: Bear Creek Burial Grounds remedial investigation data adequacy summary. DOE/OR-996\&D2 (92-225-161-63), Oak Ridge, Tennessee, January.

Radiological Health Handbook. 1970. U.S. Department of Health, Education, and Welfare, Public Health Service, Rockville, Maryland.

Ramsey, C. 1994. Soil Conservation Service, personal communication to K. Swain, April 4.

Rosensteel, B. A. and C. C. Trettin. 1993. Identification and characterization of wetlands in the Bear Creek watershed. Y/TS-1016, Martin Marietta Energy Systems, Inc., Oak Ridge National Laboratory, Oak Ridge, Tennessee, October.

Rothschild, E. R. 1984. Investigation of subsurface mercury at the Oak Ridge Y-12 Plant. ORNL/TM-9092, Martin Marietta Energy Systems, Inc., Oak Ridge National Laboratory, Oak Ridge, Tennessee.

Sacher, G. A. and E. Staffeldt. 1973. "Species differences in sensitivity of myomorph and sciuromorph rodents to life shortening by chronic gamma irradiation," in Radionuclides in Ecosystems, U.S. AEC Rep. CONF-710501-P2, Nelson, D.J. (ed.), U.S. Atomic Energy Commission, Washington, D.C., p. 1042. (cited in Whicker and Schultz 1982).

SAIC (Science Applications International Corporation). 1992. Laboratory data validation guidelines for evaluating radionuclide analyses, Rev. 4.

SAIC (Science Applications International Corporation). 1993a. Remedial investigation work plan for Bear Creek Valley operable unit 2 (Rust Spoil Area, SY-200 Yard, Spoil Area 1) at the Oak Ridge Y-12 Plant, Oak Ridge, Tennessee. DOE/OR-1060\&D3, ES/ER-43\&D3, Y/ER/Sub/91-99069/1, Environmental Restoration Program, Martin Marietta Energy Systems, Inc., Oak Ridge Y-12 Plant, Oak Ridge, Tennessee, May.

SAIC (Science Applications International Corporation). 1993b. Human health baseline risk assessment for the Northwest Plume, Paducah Gaseous Diffusion Plant, Paducah, KY. DOE/OR/07-1202\&D1, KY/ER-39.

SAIC (Science Applications International Corporation). 1994. East Fork Poplar Creek-Sewer line beltway remedial investigation report. DOE/OR/02-1119\&D2. Prepared for U.S. Department of Energy, Oak Ridge, Tennessee. 
Sanders, M. 1984. Resource management plan for the U.S. Department of Energy Oak Ridge Reservation, Volume 3, Appendix B: Archaeological considerations. ORNL-6026/V4, July.

Sanders, C. L. 1986. Toxicological aspects of energy production. Macmillan Publishing Company. New York.

Shen, T. T., C. E. Schmidt, and T. R. Card. 1993. Assessment and control of VOC emissions from waste treatment and disposal facilities. Van Nostrand Reinhold, New York.

Sheppard, J. D. 1974. Storm runoff in the vicinity of Oak Ridge, Tennessee. ORNL/TM-4662, Martin Marietta Energy Systems, Inc., Oak Ridge National Laboratory, Oak Ridge, Tennessee.

Sheppard, M. I. and D. H. Thibault. 1990. "Default soil solid/liquid partition coefficients for four major soil types: A compendium," Health Physics 59(4): 471-482.

Shevenell, L. S., R. B. Dreier, and W. K. Jago. 1992. Summary of fiscal year 1991 and 1992 construction, hydrologic and geologic data obtained from the Maynardville Limestone Exit pathway monitoring program. Y/TS-814, Oak Ridge Y-12 Plant, Oak Ridge, Tennessee, December.

Solomon, D. K. et al. 1992. Status report-A hydrologic framework for the Oak Ridge Reservation. ORNL/TM-12026, Martin Marietta Energy Systems, Inc., Oak Ridge National Laboratory, Oak Ridge, Tennessee, January.

Somer, E. 1992. "The essential guide to vitamins and minerals." Health Media of America. Harper Collins Publishers, New York.

Southworth, G. R. et al. 1992. Ecological effects of contaminants and remedial actions in Bear Creek. ORNL/TM-11977, Martin Marietta Energy Systems, Inc., Oak Ridge National Laboratory, Oak Ridge, Tennessee.

Starnes, W. C. and D. A. Etnier. 1980. "Fishes" in Tennessee's Rare Wildlife, D. C. Eager and R. M. Hatcher (eds.), Tennessee Department of Conservation, Nashville, Tennessee.

Strenge, D. L. and S. R. Peterson. 1989. Chemical data base for the multimedia environmental pollutant assessment system (MEPAS): Version 1.0. Pacific Northwest Laboratory, operated for the U.S.Department of Energy by Battelle Memorial Institute, PNL-7145, December.

Summers, K. S., S. Gherini, and C. Chen. 1980. Methodology to evaluate the potential for groundwater contamination from geothermal fluid release. EPA-600/7-80-117, as modified by U.S. Environmental Protection Agency Region IV, 1980.

Suter, G. W. 1993. Ecological risk assessment. Lewis Publisher, Chelsea, Michigan.

Suter, G. W., M. E. Will, and C. Evans. 1993. Toxicological benchmarks for screening potential contaminants of concern for effects on terrestrial plants. ES/ER/TM-85, Oak Ridge National Laboratory, Oak Ridge, Tennessee. 
Suter, G. W., B. E. Sample, D. S. Jones, and T. L. Ashwood. 1994. An approach and strategy for performing ecological risk assessments for the U.S. DOE Oak Ridge Reservation. ES/ER/TM-33/R1, Oak Ridge National Laboratory, Oak Ridge, Tennessee.

Travis, C. C. and A. D. Arms. 1988. "Bioconcentration of organics in beef, milk, and vegetation." Environ. Sci. Tech. 22:271-274.

Turner, R. F. et al. 1988. RCRA facility investigation plan, Bear Creek, Oak Ridge Y-12 Plant, Oak Ridge, Tennessee. Y/TS-417, Martin Marietta Energy Systems, Inc., Oak Ridge Y-12 Plant, December.

Turner, R. R. and G. E. Kamp. 1984. Characterization and remedial alternatives for sediments in Upper Bear Creek. Y/TS-56, Martin Marietta Energy Systems, Inc., Oak Ridge Y-12 Plant, Oak Ridge, Tennessee.

Turner, R. R. et al. 1991. Remedial investigation work plan for Bear Creek (Y02-S600) at the Oak Ridge Y-12 Plant, Oak Ridge, Tennessee. ES/ER-19\&D2 (Y/ER/Sub-90/99928/2), Martin Marietta Energy Systems, Inc., Oak Ridge Y-12 Plant, Oak Ridge, Tennessee, June.

TVA (Tennessee Valley Authority). 1985. Instream contaminant study, Task 4: Fish sampling and analysis. Report to U.S. Department of Energy, Oak Ridge Operations Office, Tennessee Valley Authority, Office of Natural Resources and Economic Development, Knoxville, Tennessee.

TVA (Tennessee Valley Authority). 1986. Instream contaminant study, Task 5: Summary report, ZZ-86-06-08.

U.S. Army Corps of Engineers. 1954. Geologic investigation-Alpha 5 Area, Y-12 Plant. Ohio River Division Laboratory.

U.S. Department of Commerce. 1991. 1990 census of population and housing: Census tracts (Knoxville), Bureau of the Census, Washington, D.C.

USDA (U.S. Department of Agriculture). 1981. Soil survey of Anderson County, Tennessee. Soil Conservation Service, U.S. Department of Agriculture, Washington, D.C.

Van Winkle, W. et al. 1984. Mercury contamination in East Fork Poplar Creek and Bear Creek. ORNL/TM-8894, Martin Marietta Energy Systems, Inc., Oak Ridge National Laboratory, Oak Ridge, Tennessee.

Verkhovshaya, I. N., V. I. Maslov, and K. I. Maslova. 1965. "The action of minute doses of radiation and incorporated natural radioactive elements on spermatogenesis in microtus oeconomus under natural conditions." Radiobiologiya 5(5): 720 . Translation: AEC-tr-6602, U.S. Atomic Energy Commission, Washington, D.C. (cited in Whicker and Schultz 1982).

Watson, D. B. and S. M. Brown. 1985. Testing and evaluation of the SESOIL model, Anderson-Nichols and Co., Inc., Palo Alto, California, p. 155. 
Welch, S. H. 1989a. RCRA facility investigation plan general document Y-12 Plant, Oak Ridge, Tennessee. Y/TS-352, Vol. 1 (Rev. 1), Martin Marietta Energy Systems, Inc., Oak Ridge Y-12 Plant, Oak Ridge, Tennessee, April.

Welch, S. H. 1989b. RCRA facility investigation plan Spoil Area I (D-107) Oak Ridge Y-12 Plant, Oak Ridge, Tennessee. Y/TS-363,(Rev.1), Martin Marietta Energy Systems, Inc., Oak Ridge Y-12 Plant, June.

Whelan, G. et al. 1987. The remedial action priority systems (RAPS): Mathematical formulations. Prepared for Assistant Secretary, Environment, Safety, and Health, Office of Environmental Guidance and Compliance, U.S. Department of Energy, Washington, D.C., prepared by Pacific Northwest Laboratory, Richland, Washington-99352, DOE/RL/87-09, PNL-6200, pp. 8-11.

Whicker, F. W. and V. Schultz. 1982. Radioecology: Nuclear energy and the environment. CRC Press, Boca Raton, Florida, pp. 119-180.

WHO (World Health Organization). 1978. Environmental Health Criteria.5. Nitrates, nitrites, and $N$-nitroso compounds. United Nations Environment Program and the World Health Organization, Geneva, Switzerland.

Winter, R. 1979. Cancer causing agents: A preventive guide. Crown Publishers, Inc., New York.

Woodwell, G. M. 1962. "Effects of ionizing radiation on terrestrial ecosystems." Science 138: $572-577$.

$\mathrm{Yu}, \mathrm{C}$. et al. 1993. Manual for implementing residual radioactive material guidelines using RESRAD, Version 5.0, DOE/CH/8901 (ANL/EAD/LD-2). 


\section{DISTRIBUTION}

1. L. V. Asplund

2. V. J. Brumback

3. D. G. Cope

4. J. T. Fowler

5. B. Fuhrer

6. J. D. Gass

7. C. D. Goins

8. C. S. Haase

9. P. H. Hight

10. J. A. Hodgins

11. L. M. Houlberg

12. J. B. Hunt

13. W. K. Jago

14. D. S. Jones

15. C. W. Kimbrough

16. H. L. King

17-18. A. K Lee/DOE-OSTI

19. J. M. Loar

20-22. D. M. Matteo

23. M. McKinney

24. L. W. McMahon

25. T. I. Nakamoto

26. H. C. Newsom/D. C. White

27. B. Nourse

28-29. P. T. Owen

30. C. M. Smith

31. R. J. Spence

32. G. W. Suter

33. T. S. Tison

34. R. R. Turner

35. C. S. Walker

36. D. Watson

37. J. L. Webb

38. R. W. Weigel

39. R. K. White

40. Y-12 Technical Library

41-43. ER Central Document Management Center

44. Y-12 Document Management Center

45. Y-12 Central Files

46. P. Delfonzo, Foster Wheeler Company, 111 Union Valley Road, Oak Ridge, TN 37830

47. J. A Archer, Jacobs Engineering, 800 Oak Ridge Turnpike, Oak Ridge, IN 37830

48. R. Stewart, Jacobs Engineering, 800 Oak Ridge Turnpike, Oak Ridge, TN 37830

49. J. Darden, MK-Ferguson of Oak Ridge, P.O. Box 2011, Oak Ridge, TN 37831

50. A. Bailey, Science Applications International Corporation, P.O. Box 2501, 800 Oak Ridge Turnpike, Oak Ridge, TN 37831

51. P. J. Halsey, DOE Oak Ridge Operations Office, P.O. Box 2001, Oak Ridge, TN 37831-8541

52-61. S. L. Lankford, DOE Oak Ridge Operations Office, P.O. Box 2001, Oak Ridge, TN 37831-8541

62-63. R. L. Nace, Branch Chief, Nonenrichment Facilities, Oak Ridge Program Division, Office of Eastern Area Programs, Office of Environmental Restoration, EM-423, Trevion 2, U.S. Department of Energy, Washington, DC 20585

64. R. C. Sleeman, DOE Oak Ridge Operations Office, P.O. Box 2001, Oak Ridge, TN 37831-8541

65-66. H. M. Thron, Chief, Enrichment Facilities, Oak Ridge Program Division, Office of Eastern Area Programs, Office of Environmental Restoration, EM-423, Trevion 2, U.S. Department of Energy, Washington, DC 20585 